\title{
Use of hydrogeophysical data to determine the role of faults in the geometry of the Barreiras Aquifer, Brazil
}

\author{
Isaac Vinícius Fagundes de Souza' (D), Leandson Roberto Fernandes de Lucena ${ }^{1,2 *}$ (D), \\ Francisco Hilário Rego Bezerra ${ }^{1,3}$ (D), José Braz Diniz Filho ${ }^{3}$ (D)
}

\begin{abstract}
Characterizing the geometry of an aquifer is fundamental for determining the locations of more productive wells. Commonly, flow and hydraulic parameters, such as transmissivity, are related to the thickness of the aquifer, which emphasizes the importance of regional hydrogeophysical characterization. Shuttle radar imagery, well profiles and geoelectric models (thickness $\mathrm{x}$ resistivity) from sixteen soundings were used to identify Neogene faults in the Barreiras Aquifer in the Catu River basin, northeastern Brazil. The joint analysis of the geomorphological data enabled the development of a synthesis map characterizing morphotectonic alignments that are mainly $\mathrm{N} 50^{\circ}-60^{\circ} \mathrm{E}$ and $\mathrm{N} 40^{\circ}-60^{\circ} \mathrm{W}$ trending. A number of these alignments were interpreted as faults based on 10 to 44 throws that were identified in the hydrogeophysical cross-sections. The highest values were located in the northeastern portion of the area, suggesting the direct association between saturated thickness and Neogene faults. Additionally, the geoelectric and hydraulic head data of the aquifer allowed the identification of the most promising sites for future water exploitation in the northeastern portion of the study area with transverse resistances equal to or greater than 40,000 Ohm.m. The geometry and transmissivity of the Barreiras Aquifer indicate that porous aquifers in structural highs could be controlled by faults.
\end{abstract}

KEYWORDS: neogene fault compartmentalization; aquifer geometry; hydrogeophysics; Barreiras Formation Aquifer; Brazil.

\section{INTRODUCTION}

Understanding the factors that influence aquifer thickness and geometry has become essential in reservoir modeling and for the identification of potential locations of more productive wells in the future. The influence of lithology, hydrological basement and faults on porosity and permeability remains a matter of debate, especially the quantification of these parameters (Burazer et al. 2010). In tectonic-structural terms, such structures as grabens and horsts can influence the aquifer geometries by controlling the space for sedimentary deposition of further saturated bodies (Díaz et al. 2014). In addition, faults and artificial structures also play important roles in permeability, acting either as a barrier slowing the flow of water or as conduits between aquifers (e.g., Pujades et al. 2012, Font-Capo et al. 2015). Although the relationship between faults and aquifer geometry has already been established for several areas, such as southern California, USA (Landon et al. 2015) and southeastern Tunisia (Chihi et al. 2015), more

\footnotetext{
${ }^{1}$ Graduate Program on Geodynamics and Geophysics, Federal University of Rio Grande do Norte - Natal (RN), Brazil.

E-mail: isaac.geomin@yahoo.com.br

${ }^{2}$ Geophysics Department, Campus Universitário, Federal University of Rio Grande do Norte - Natal (RN), Brazil. E-mail: leandson@geofisica.ufrn.br ${ }^{3}$ Geology Department, Campus Universitário, Federal University of Rio Grande do Norte - Natal (RN), Brazil.

E-mails: bezerrafh@geologia.ufrn.br, brazdf@geologia.ufrn.br

${ }^{*}$ Corresponding author.
}

(C) 2019 The autors. This is an open access article distributed unde the terms of the Creative Commons license. study cases are needed to fully understand the role of faults on aquifer properties.

Studies on the influence of faults on aquifers in Brazilian sedimentary basins have emphasized the role of regional geological structures on the petrophysical (Balsamo et al. 2013) and hydrogeological behavior (Lucena et al. 2013) of Miocene and Quaternary sedimentary units. These basins of the eastern coast in northeastern Brazil feature faults with several trends, some of which form boundaries between horsts and grabens (Bezerra et al. 2008). Notwithstanding the structural characterization of Cenozoic basins, the relationships among tectonic structures and aquifer parameters have not been thoroughly elucidated to date.

The primary objective of this study is to characterize the geometry of the Barreiras Formation Aquifer and its relationship with regional structures. Second, we aim to identify the most promising areas of transmissivity associated with the positive anomalies of saturated thickness. We assumed that the variations of saturated thickness may be associated with faults in the hydrogeological basement, which also affect the overlapping stratigraphic units, particularly the Barreiras Formation.

Our study area is the Catu River basin (Fig. 1) in northeastern Brazil. The scarcity of well data is observed because $\sim 90 \%$ of the area of the basin is occupied by sugarcane crops, which utilize surface water for irrigation. This scarcity made the use of electrical resistivity surveys an imperative factor to complement the hydrostratigraphic characterization of the aquifer. Additionally, we applied geoelectrical parameter of transverse resistance (Orellana 1972) to observe the transmissivity in sedimentary aquifers (Utom et al. 2012). 


\section{GEOLOGICAL SETTING}

The study area comprises the coastal Catu River basin, which was formed during the breakup of Pangea, in the Cretaceous (Moulin et al. 2011, De Castro et al. 2012). This sedimentary basin exhibits a monoclinal geometry with a gentle dip toward the ocean to the east (Bezerra et al. 2014). The region is composed of a crystalline basement capped by Cretaceous, Miocene, and Quaternary units (Rossetti et al. 2011). The Archean and Proterozoic crystalline basement (granites, gneisses, and migmatites), and the Cretaceous sandstones (Açu Formation) and limestones (Jandaíra Formation) do not outcrop in the Catu River basin. The top of the Cretaceous sequence is marked by mudstone with carbonate cement (Lucena 2005). The present study mainly focuses on the Miocene Barreiras Formation (Fig. 1), which is composed of sandstones to argillaceous sandstones with clay and conglomerate intercalations. Quaternary sedimentary units cap the Barreiras Formation and are composed of aeolian and alluvial deposits, sandy-clay, marine and fluvial-marine sediments (Rossetti et al. 2011, Da Guia Lima et al. 2014).

The crystalline basement in the region exhibits several steep ductile shear zones, which were reactivated as strike-slip and normal faults during the Cretaceous and the Neogene-Quaternary (Bezerra et al.2014, Lima et al.2014). The Neogene faults strike mainly $040^{\circ}-060^{\circ}(\mathrm{NE}-\mathrm{SW}), 300^{\circ}-320^{\circ}(\mathrm{NW}-\mathrm{SE})$ and $350^{\circ}-$ $010^{\circ}(\mathrm{N}-\mathrm{S})$ (Bezerra et al. 2014, Lima et al. 2014). These structures are characterized by strike-slip and normal movements, which is associated with syn-sedimentary deformation that resulted from a maximum horizontal E-W-oriented compression that started in the Neogene period (Bezerra et al. 2001). This compression favored the formation of dextral NE-SWand sinistral NW-SE-striking strike-slip faults, respectively. These faults result in a general horst and graben structure along the coast, which is the subject of the present study.

\section{REGIONAL HYDROGEOLOGICAL FEATURES}

The Barreiras Aquifer System is one of the main water resources of the Brazilian coast. This system encompasses Miocene sandstone deposits along more than $5,000 \mathrm{~km}$ of coastal areas from latitude $5^{\circ} \mathrm{N}$ to latitude $20^{\circ} \mathrm{S}$ (Rossetti et al. 2013). The lower limit of the aquifer in the study area is the top of the Cretaceous carbonate unit, which does not outcrop in the Catu River basin. This layer is composed of coarse-clay sediments to clay with a calcite cement (calciferous sandstone/ marl) and low groundwater productivity. The crystalline basement also forms the lower limit of the aquifer at a few locations (Lucena et al. 2013). The Barreiras Aquifer exhibits variable hydraulic conditions but mainly has an unconfined hydraulic character (Lucena 2005).

The Barreiras Aquifer exhibits pumping rates of up to $0.04 \mathrm{~m}^{3} / \mathrm{s}$ in some wells along the coast of northeastern Brazil (Lucena 2005). However, lower values also occur, which are mostly associated with the reduced thickness of the Barreiras Formation. The values of transmissivity reported in the study area and the surrounding region by Lucena (2005) are $2.8 \times 10^{-3}$ to $9.2 \times 10^{-3} \mathrm{~m}^{2} / \mathrm{s}$. In the area of the Catu River basin, hydraulic transmissivity $(\mathrm{T})$ values of $2.63 \times 10^{-3} \mathrm{~m}^{2} / \mathrm{s}$ and hydraulic conductivity $(\mathrm{K})$ values of $5.98 \times 10^{-5} \mathrm{~m} / \mathrm{s}$ were reported, considering a saturated average thickness of $44 \mathrm{~m}$ (Monteiro 2015). Hydraulic conductivity values in the order of $10^{-3} \mathrm{~m} / \mathrm{s}$ were also observed by Lucena et al. (2016) in other sandstone aquifers near the study site.

The potentiometric map of the study area (Fig. 2) illustrates the main flow from west to east toward the coast line in addition to other secondary flows converging toward the Catu River; the area features a natural discharge of the aquifer and extensive interaction with the surface drainage.

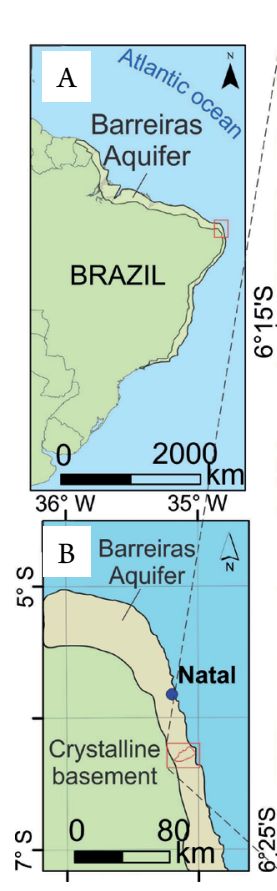

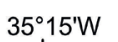

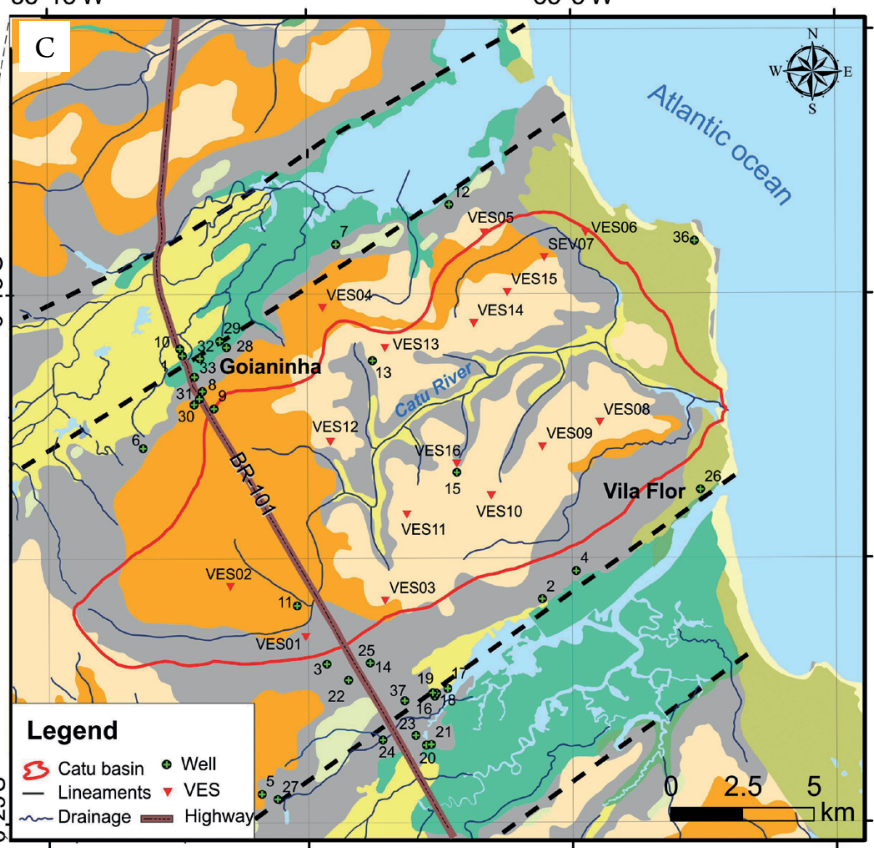

$\mathrm{D}$

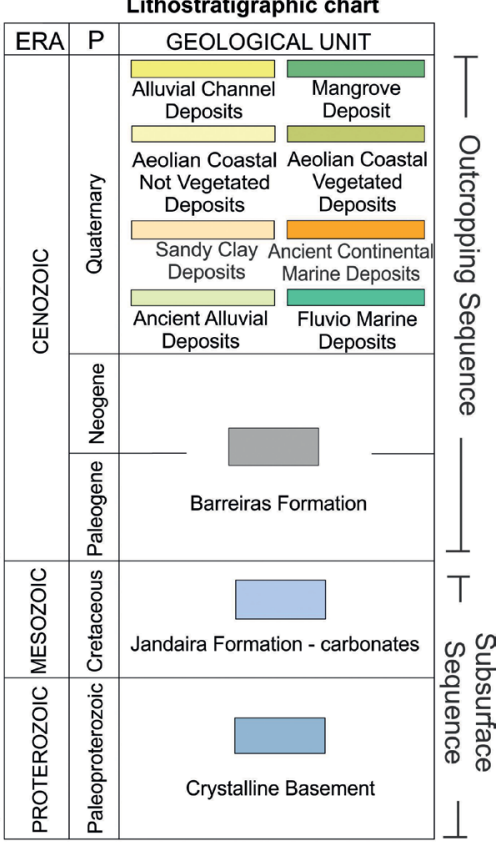

Figure 1. (A) Eastern part of South America and location of the Barreiras Formation along the coast; (B) location and (C) geologic map of study area; (D) local stratigraphy with geological units of Miocene-Quaternary age (outcropping units), and Archean-Proterozoic and Cretaceous units (non-outcropping units) of the study area (modified from Lima et al. 2014). 
The maximum and minimum hydraulic gradients in the Barreiras Aquifer are observed in the central and northeastern part of the basin area, with values of $16.6 \times 10^{-3}$ and $0.83 \times 10^{-3}$, respectively (Monteiro 2015). A well profile in the study area is shown in Fig. 2B, which highlights the sequence of fine to medium sands, which are added to the hydrogeological basement represented by mudstones with carbonate cement at $64 \mathrm{~m}$ depth.

\section{METHODOLOGY}

\section{Morphotectonic and hydrographic analyses}

We performed a geomorphological analysis in the Catu River basin and its surrounding area, considering the regional geology. The analysis identified lineaments associated with the main directions of the drainage network and topographic breaks associated with faults. We used the Shuttle Radar Topography Mission (SRTM) data (Valeriano and Albuquerque 2010) to draw the topographic and drainage lineaments. This methodology was chosen because of the reduced number of outcrops, and the information regarding fault kinematics that would provide better detail of features associated with the structural framework. The SRTM data were processed with the use of graphics, geostatistical interpolation and gridding in GIS software (Esri 2014). The drainage lineaments were quantified and presented in the form of rose diagrams.

The topographic analysis was performed using the SRTM data with horizontal spatial resolution of $75 \times 75 \mathrm{~m}$ and processed using kriging interpolation and gridding (Christakos 2000). The topographic relief with contour lines spaced every $10 \mathrm{~m}$ was generated to trace the topographic lineaments.
We used topographic products to identify geological lineaments. The regional map was generated by applying a low pass filter on the entire topographic map to reveal the regional $\mathrm{W}$-E-oriented gradient toward the ocean. This filter attenuates spatial high frequencies to smooth the contour-line data. Different parameterization filter arrays (order 3, 5 and 9) were used for better data smoothing. The residual map was obtained from the subtraction of the total component in relation to the regional component $(\mathrm{Res}=\mathrm{T}-\mathrm{R})$ to highlight some of the local anomalies and topographic lineaments associated with isoline continuity and/or the boundaries between topographic highs and lows. This process generates fluctuations between positive and negative values from zero, which outlines anomalous features. A residual map was associated with each regional topographic map.

We identified anomalies in the drainage networks, the standard river behavior, and their main flow directions, and checked the combination of these features with the fault occurrence and orientation. Anomalies in drainage networks, when embedded in the structures, produce peculiar features, such as:

- springs;

- abrupt deflections of fluvial channels;

- alignment of lagoons; and

- linear water bodies.

The drainage lineaments were drawn from the hillshade SRTM image. We highlighted the main drainage networks using azimuthal illumination and vertical exaggeration. The azimuth directions were chosen to image structures orthogonal to the direction of illumination and to be able to enhance their geometry. The illumination azimuths were $0^{\circ}, 45^{\circ}, 90^{\circ}$ and the vertical exaggerations were $2 \mathrm{x}, 10 \mathrm{x}$, and $30 \mathrm{x}$.

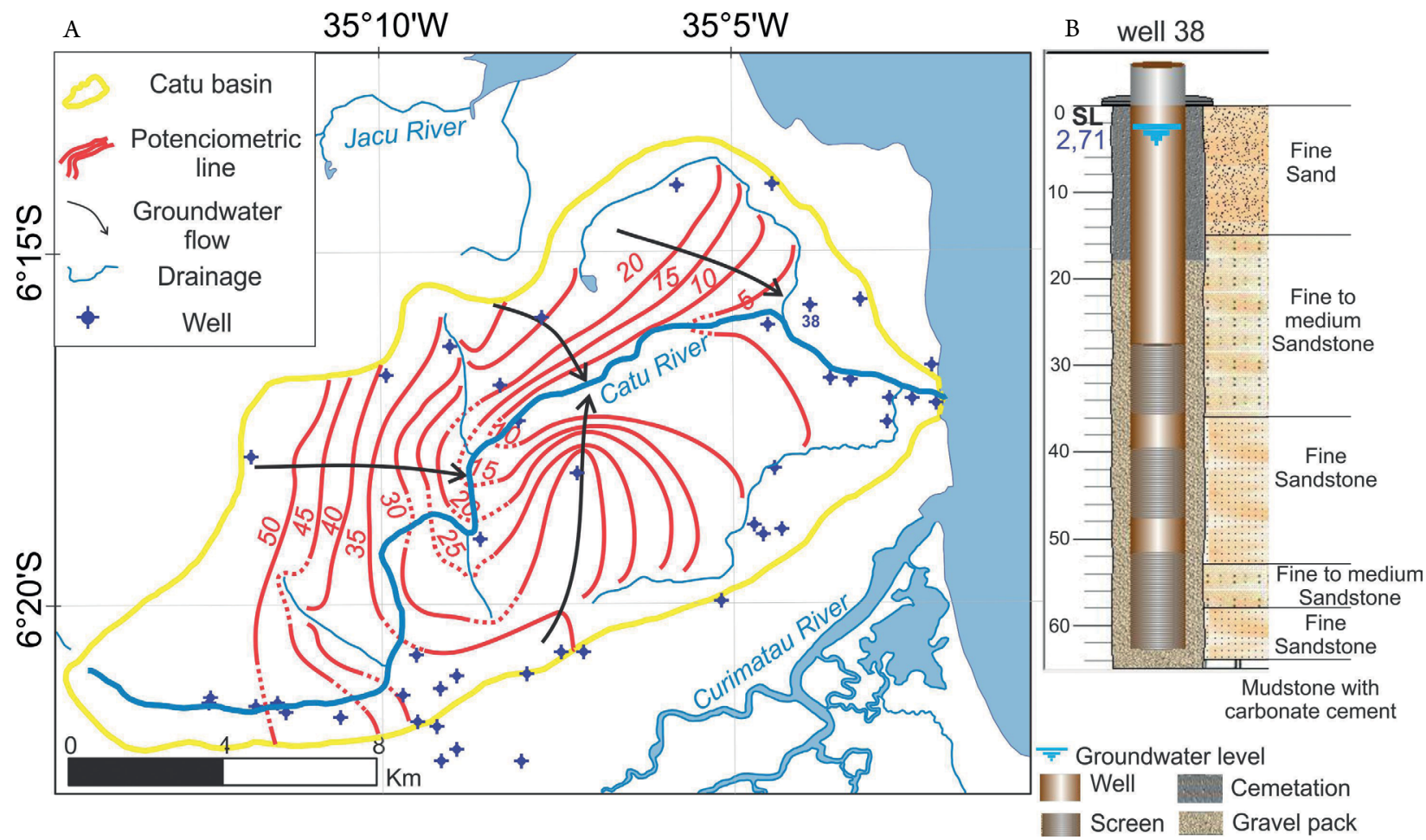

Figure 2. Potentiometric map of Barreiras Aquifer in Catu River basin area (A) (adapted from Monteiro 2015), and the hydrostratigraphic profile of well-38, located in the northeastern part of the study area (B). The hydrogeological basement is $64 \mathrm{~m}$ deep and is composed of calciferous sandstone or marl (top of the Cretaceous carbonate unit). 


\section{Hydrogeophysical analysis}

The electrical resistivity method was implemented with the vertical electrical sounding technique (VES) and the Schlumberger electrode array to investigate the basin. Sixteen VES runs were performed, which enabled the investigation of the resistivity variations as a function of depth. We applied a flat and parallel layer model consistent with the geology of the study area (Bezerra et al.2014), and the following conditions after Orellana (1972):

- the subsoil consists of a sequence of layers with finite thickness (Ei), except the deepest one, which is assumed to have an infinite thickness;

- each layer is assumed to be electrically homogeneous and isotropic, characterized by a resistivity $(\rho)$; and

- the separation interfaces between the layers are flat and horizontal, and parallel to the Earth's surface.

The locations of VES were chosen to supplement the lack of subsurface information from well logs. Interpretations of VES were performed using the IPI2Win software (Bobachev et al. 2000); this inversion software specializes in handling VES data. The software calculates "resistivity $\mathrm{x}$ thickness" models from an apparent resistivity curve, which represents the variation of the physical parameter $(\rho)$ as a function of depth and emphasizes the geoelectrical saturated and unsaturated thicknesses.

Since there are no electric well logs to provide the resistivity of in situ values of the various stratigraphic layers, we considered the calibration of geoelectric models using electrical soundings performed by Lucena (2005) in the Barreiras Aquifer. An additional geoelectric calibration was also employed in the study area. These soundings were implemented adjacent to wells with known stratigraphic profiles. This procedure allowed the definition of representative values of the different hydrostratigraphic horizons to support the quantitative interpretation of other VES.

The resistivity $\mathrm{x}$ thickness models from VES allowed the measurement of transverse electrical resistance (Orellana 1972), which was subsequently interpolated to obtain a transverse electrical resistance map. These values are derived by the product of the thickness and their resistivities (Orellana 1972) and consider the saturated zone, where the higher values associated with a more substantial transmissivity (higher thickness and/or resistivity compatible with sand layer).

The models obtained with the interpretation of VES were added to the available information from well logs to perform the structural characterization of the area. We selected wells with complete lithological profiles and that reached the hydrogeological basement of the Barreiras Aquifer (calciferous sandstone or marl).

The topographic and drainage lineaments are included in a morphotectonic map that includes the most important alignments. The integration of geoelectric, topographic, and well data enabled us to produce maps of the hydrogeological basement, saturated thickness, transverse resistance, and four hydrogeophysical cross-sections. The cross-sections were detailed and planned in order to intercept the roughly orthogonal morphotectonic alignments. The altimetric values used in the cross-sections were obtained from SRTM images and corrected to the mean sea level. Next, we constructed a detailed geological map of the area and established the correlation between the potentiometric and the geoelectric map to select the most promising targets for well locations.

\section{RESULTS AND DISCUSSION}

The parameterization using the $9 \times 9$ low-pass filter on the regional topographic map yielded results that showed a regional E-W-oriented topographic gradient. The residual topographic map (Fig. 3A) also provided results with the $9 \times 9$ matrix configuration. However, it was not possible to observe local topographic anomalies by comparing these results with the results from the $5 \times 5$ and $9 \times 9$ filters. Thus, it was necessary to perform a detailed analysis of the valley areas to verify the continuity of isolines and to associate these anomalies with geomorphological parameters derived from satellite images. This procedure indicated that the $9 \times 9$ matrix was the best filter.

After the application of filters and the separation of regional and residual components, we identified $81 \mathrm{NW}$ - and NE-oriented topographic lineaments (Fig. 3A). Considering the parameters $\left(\mathrm{Az}=0^{\circ}\right.$ and $\left.\mathrm{Z}=10 \mathrm{x}\right)$, we drew 1107 drainage lineaments and plotted the results on rose diagrams. Fig. 3B shows a summary of these results with emphasis on the regional drainage lineaments in the rose diagram. The NE-SW-striking faults identified in the study area coincide with NE-SW-striking shear zones in the crystalline basement in the area. The faults mapped in the sedimentary basin are characterized by brittle reactivations of the ductile shear zones in the basement (Bezerra et al. 2001).

We standardized the drainage lineaments of the Catu River basin with the same weight to observe their behavior and correlate them with the main regional morphotectonic directions. We adopted a $200 \mathrm{~m}$ unit for each lineament, considering the size of the lineaments and the scale of the map. We obtained 1,235 drainage lineament units measuring $200 \mathrm{~m}$ each. After standardizing the drainage lineaments (Fig. 3C), they were plotted in rose diagrams. The results mainly show $\mathrm{N} 30^{\circ}-50^{\circ}-\mathrm{E}$ and $\mathrm{N} 30^{\circ}-40^{\circ} \mathrm{W}$-oriented trends.

The topographic and drainage lineaments suggest that the main morphotectonic alignments represent evidence of the structural compartmentalization of the study area (Fig. 3). These alignments allowed the identification of faults in the images, which were combined with subsurface data to quantify vertical fault throws.

The geoelectric calibration (Fig. 4A) was performed adjacent to a well with a known lithological profile located in the Catu River basin (Fig. 4B). The adjustment of the geoelectric data along with the hydrogeological information of the well produced a model consisting of six geoelectric layers, including the hydrogeological basement, and saturated and unsaturated zones. It follows that there are some values of apparent anomalous resistivity, which are mostly those related to electrodes $\mathrm{AB} / 2$ of 50 and $60 \mathrm{~m}$ and that were not considered in the adjusted model. The peak feature at the center of Fig. 4A represents unstable measurements, which did not allow the stratigraphic correlation with the adjacent well lithological 
profile (Fig. 4A). Additional geoelectric calibration data of the Barreiras Aquifer obtained by Lucena (2005) were also incorporated to the dataset.
The vertical electrical soundings (Table 1 ) were located throughout the Catu River basin (Fig. 2). Fig. 5 exhibits examples of resistivity curves and the interpreted geoelectric model,

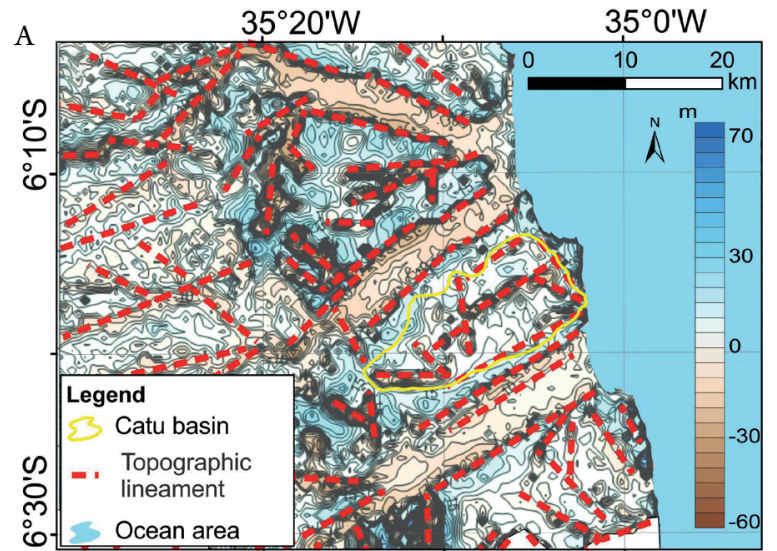

B
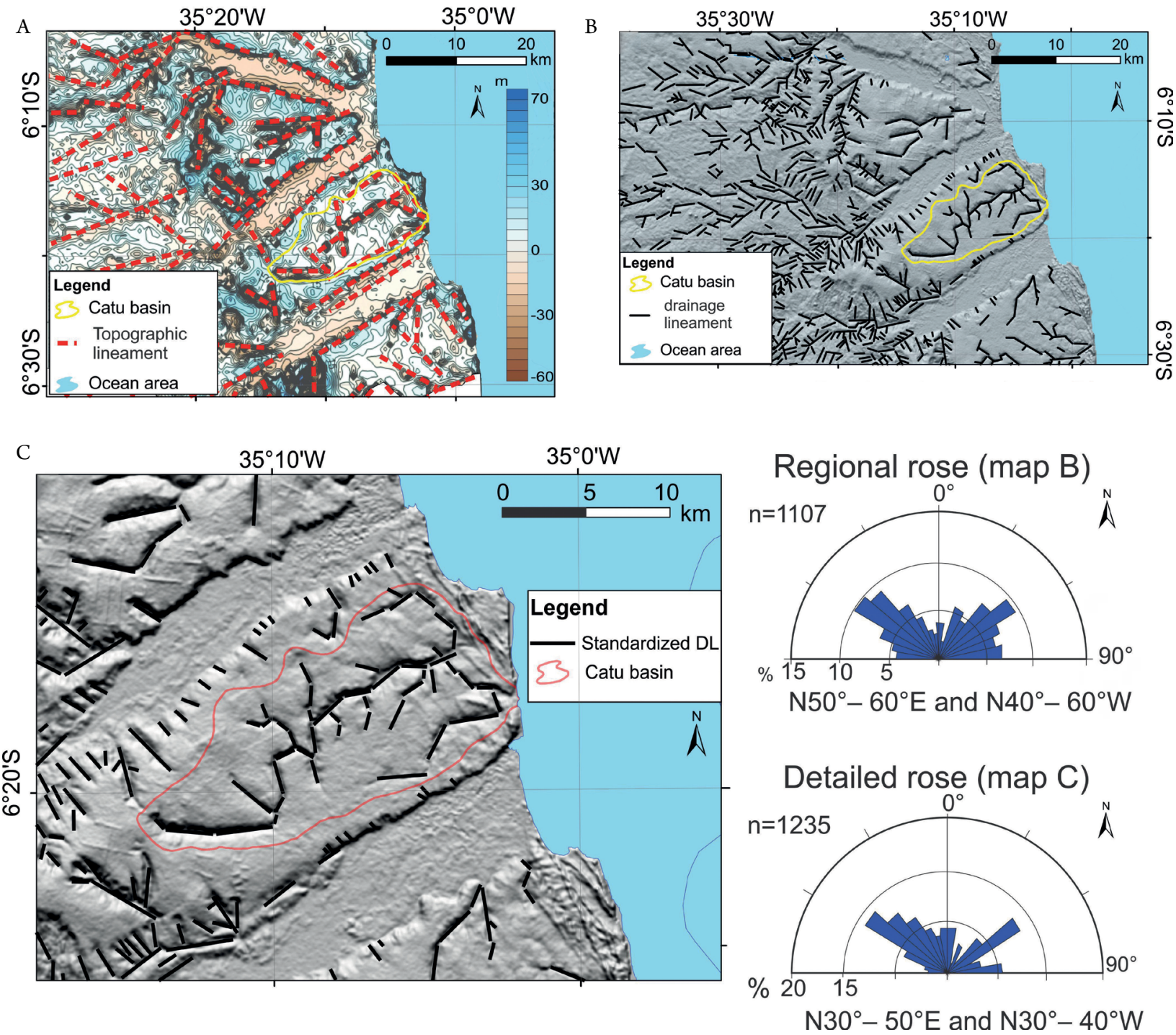

Figure 3. Maps of topographic and drainage lineaments: (A) topographic lineaments, (B) drainage lineaments, and (C) drainage lineaments on the sedimentary units. The regional and detailed rose diagrams are also included, where each lineament unit corresponds to $200 \mathrm{~m}$.

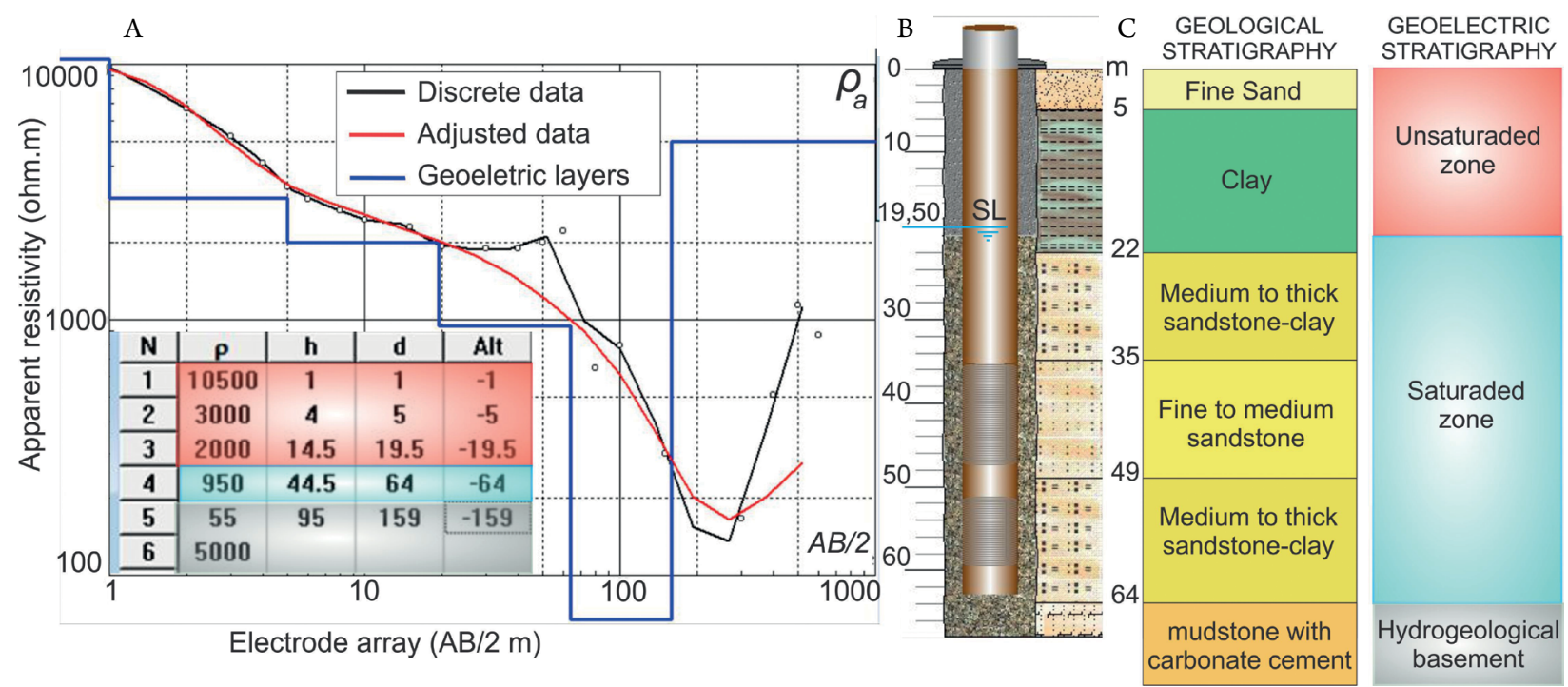

Figure 4. Geoelectric sounding: (A) apparent resistivity curve (VES-16) and its adjustment by the model with six geoelectric horizons: $\mathrm{N}$ represents the number of layers, $\mathrm{h}$ and $\mathrm{d}$ refer to the layer thickness and depth, respectively; (B) well design; (C) hydrogeoelectrical lithology and corresponding stratigraphy. The geoelectrical basement corresponds to a conductive marl. 
which were reinterpreted from the original data by Monteiro (2015). The values of the unsaturated and saturated thicknesses of VES are shown in the internal tables of the figures.

We used data from 38 wells that reach the top of the calciferous sandstone/marl (Table 2) to map the hydrogeological basement of the Barreiras Aquifer. The maximum depths of the hydrogeological basement are $93 \mathrm{~m}$ in well 26 and $97 \mathrm{~m}$ in VES-15. The hydrogeological basement (Fig. 6) exhibits an E-W trending regional gradient, which deepens toward the coastline. We observed a prominent geoelectric anomaly in the northeastern part of the map, displaying the deeper horizons of the hydrogeological basement of the Barreiras Aquifer.

The hydrogeophysical cross-sections are the result of the joint interpretation of morphotectonic alignments and subsurface

Table 1. Vertical electrical soundings. UT $(\mathrm{m})$ represents the unsaturated thickness, ST (m) the saturated thickness, and GB (m) the top of the geoelectrical basement. $\mathrm{X}$ represents the latitude, $\mathrm{Y}$ the longitude, and $\mathrm{Z}$ the altitude of well. The altimetric values $(\mathrm{Z})$ were collected using remote sensing images of the Shuttle Radar Topographic Mission.

\begin{tabular}{|c|c|c|c|c|c|c|}
\hline VES & $\mathbf{X}$ & $\mathbf{Y}$ & $\begin{array}{c}\mathbf{Z} \\
(\mathbf{m})\end{array}$ & $\begin{array}{l}\text { UT } \\
(\mathbf{m})\end{array}$ & $\begin{array}{l}\text { ST } \\
(\mathbf{m})\end{array}$ & $\begin{array}{l}\text { GB } \\
(\mathbf{m})\end{array}$ \\
\hline 1 & $6^{\circ} 21^{\prime} 31^{\prime \prime}$ & $35^{\circ} 10^{\prime} 12^{\prime \prime}$ & 68 & 19.0 & 48.0 & 67.0 \\
\hline 2 & $6^{\circ} 20^{\prime} 33^{\prime \prime}$ & $35^{\circ} 11^{\prime} 39^{\prime \prime}$ & 100 & 64.0 & 10.0 & 74.0 \\
\hline 3 & $6^{\circ} 20^{\prime} 50^{\prime \prime}$ & $35^{\circ} 08^{\prime} 41^{\prime \prime}$ & 61 & 27.5 & 40.0 & 67.5 \\
\hline 4 & $6^{\circ} 15^{\prime} 13^{\prime \prime}$ & $35^{\circ} 09^{\prime} 51^{\prime \prime}$ & 54 & 12.5 & 30.0 & 42.5 \\
\hline 5 & $6^{\circ} 13^{\prime} 47^{\prime \prime}$ & $35^{\circ} 06^{\prime} 45^{\prime \prime}$ & 42 & 11.0 & 40.0 & 51.0 \\
\hline 6 & $6^{\circ} 13^{\prime} 48^{\prime \prime}$ & $35^{\circ} 04^{\prime} 49^{\prime \prime}$ & 47 & 16.0 & 36.0 & 52.0 \\
\hline 7 & $6^{\circ} 14^{\prime} 16^{\prime \prime}$ & $35^{\circ} 05^{\prime} 36^{\prime \prime}$ & 46 & 4.0 & 79.0 & 83.0 \\
\hline 8 & $6^{\circ} 17^{\prime} 25^{\prime \prime}$ & $35^{\circ} 04^{\prime} 33^{\prime \prime}$ & 36 & 30.0 & 62.0 & 92.0 \\
\hline 9 & $6^{\circ} 17^{\prime} 53^{\prime \prime}$ & $35^{\circ} 05^{\prime} 39^{\prime \prime}$ & 42 & 8.5 & 78.0 & 86.5 \\
\hline 10 & $6^{\circ} 18^{\prime} 49^{\prime \prime}$ & $35^{\circ} 06^{\prime} 38^{\prime \prime}$ & 46 & 20.5 & 68.0 & 88.5 \\
\hline 11 & $6^{\circ} 19^{\prime} 11^{\prime \prime}$ & $35^{\circ} 08^{\prime} 15^{\prime \prime}$ & 53 & 24.5 & 35.0 & 59.5 \\
\hline 12 & $6^{\circ} 17^{\prime} 47^{\prime \prime}$ & $35^{\circ} 09^{\prime} 43^{\prime \prime}$ & 58 & 10.0 & 45.0 & 55.0 \\
\hline 13 & $6^{\circ} 15^{\prime} 60^{\prime \prime}$ & $35^{\circ} 08^{\prime} 40^{\prime \prime}$ & 54 & 19.0 & 54.0 & 73.0 \\
\hline 14 & $6^{\circ} 15^{\prime} 32^{\prime \prime}$ & $35^{\circ} 06^{\prime} 60^{\prime \prime}$ & 53 & 34.0 & 18.0 & 52.0 \\
\hline 15 & $6^{\circ} 14^{\prime} 55^{\prime \prime}$ & $35^{\circ} 06^{\prime} 19^{\prime \prime}$ & 49 & 2.5 & 95.0 & 97.2 \\
\hline 16 & $6^{\circ} 18^{\prime} 12^{\prime \prime}$ & $35^{\circ} 07^{\prime} 19^{\prime \prime}$ & 49 & 19.5 & 44.5 & 64.0 \\
\hline
\end{tabular}

data (Fig. 7). We prepared four sections (A-A', B-B', C-C', and $\left.\mathrm{D}-\mathrm{D}^{\prime}\right)$ that intercept the morphotectonic alignments orthogonally. The throws were mainly identified by the changes in the top of the carbonate sequence (calciferous sandstone or marl) and the hydrogeological basement of the Barreiras Aquifer.

The A-A' cross-section (Fig. 7) is $\sim 22 \mathrm{~km}$ long and NW-SEoriented, and crosscuts the Catu River. This cross-section exhibits 10 to $22 \mathrm{~m}$ throws of the hydrogeophysical basement. The throws in the southern part of the section were calculated using VES-01 and well 11, which yielded a vertical offset of $10 \mathrm{~m}$. In the northern part of the cross-section, the throws reach $26 \mathrm{~m}$ and were quantified using the depth of the hydrogeophysical basement in wells 1, 6, 30, and 33 .

The B-B' cross-section is $\sim 16 \mathrm{~km}$ long, intercepts the Catu River and is associated with the morphotectonic alignments. The throws range from 20 to $44 \mathrm{~m}$, and the maximum throw values occur between VES-09 and VES-14. In the southern part of the cross-section, the correlation of the hydrogeophysical data between well 2 and VES-10 yielded a throw of $\sim 20 \mathrm{~m}$.

The C-C 'and D-D' cross-sections are both $\sim 22 \mathrm{~km}$ long and trend NE-SW. In the C-C' cross-section, the most significant throw is $41 \mathrm{~m}$ and occurs between VES-14 and VES- 15 . Throws of $40 \mathrm{~m}$ occur between VES-06 and well 36. In the D-D' cross-section, the main throws occur between VES-16 and well 15. The throws reach $38 \mathrm{~m}$ and $37 \mathrm{~m}$ between VES16 and VES- 11 and between well-15 and VES-10, respectively.

The information from the hydrogeophysical cross-sections (Fig. 7) and the related morphotectonic features in the subsurface allowed for the characterization of normal faults in the Catu River basin (Fig. 8). The throws along faults were determined using subsurface data and morphotectonic features. The lack of morphotectonic lineaments, however, indicates that some faults are blind.

The data in Tables 1 and 2 were also used to establish a thickness map of the Barreiras Aquifer (Fig. 9). The maximum values of saturated thicknesses in the wells were $53.6 \mathrm{~m}$ in well 36 and $97 \mathrm{~m}$ in VES-15. In general, the largest aquifer thicknesses occur in the eastern and northeastern parts of the basin.

Interpretative geoelectric models of vertical electrical soundings, in turn, also made it possible to develop a transverse geoelectric resistance map, which included the geoelectric layers corresponding
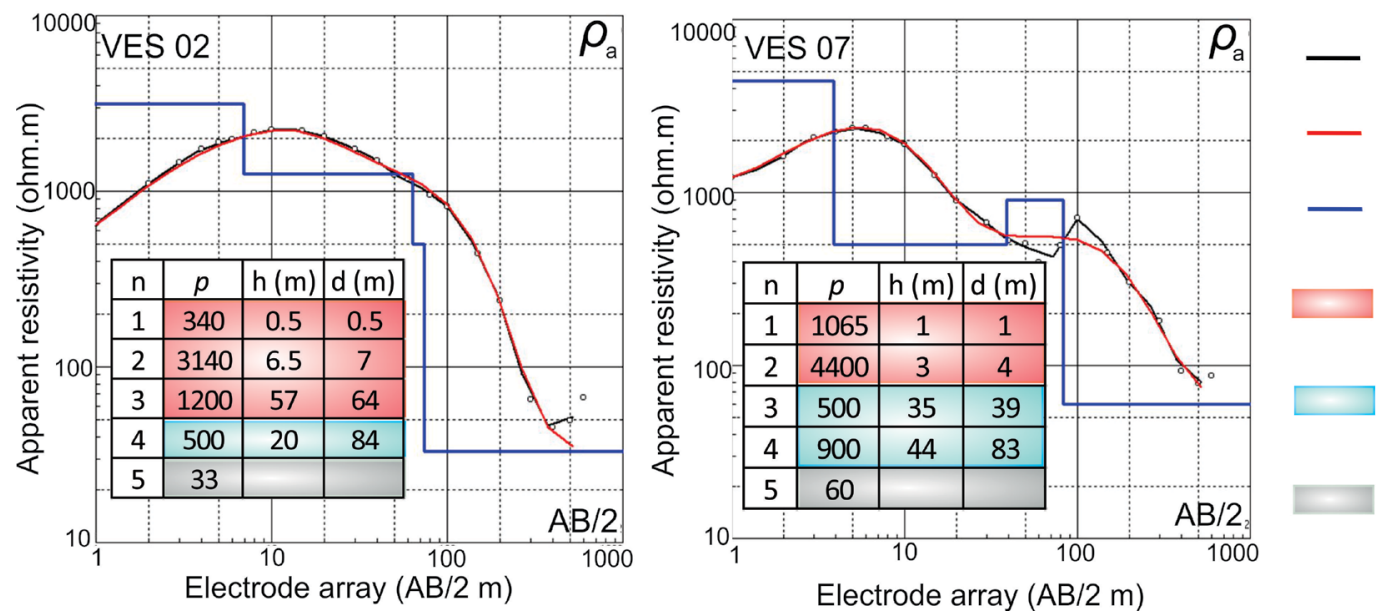

Discrete data

Adjustment model

Geoeletric layers

Unsaturaded

thickness

Saturaded thickness

Hydrogeological basement

Figure 5. Vertical electrical soundings VES-02 and VES-07, and their geoelectric models, emphasizing the saturated and unsaturated thicknesses. 
to the saturated zone (Fig. 10). The values of transverse resistance range from 2,000 to $54,000 \mathrm{Ohm} . \mathrm{m}^{2}$. The geoelectric interpretation of the saturated layers yielded resistivity values between 350 and $950 \mathrm{Ohm} . \mathrm{m}$, which are related to the occurrence of sandstones with without clay (low and high resistivity, respectively).

Table 2. Well data obtained near the River Catu basin. The X, Y and $\mathrm{Z}$ values correspond to geographic coordinates and altitude, respectively. SL (m) corresponds to the well static level in the top of the aquifer, $b(\mathrm{~m})$ is the thickness of the aquifer, and HB (m) the top of the hydrogeological basement (aquifer base). Data from the Water and Sewage Company of the State of Rio Grande do Norte (CAERN).

\begin{tabular}{|c|c|c|c|c|c|c|}
\hline Well & $\mathbf{S}$ & $\mathbf{W}$ & $\begin{array}{c}\mathbf{Z} \\
(\mathbf{m})\end{array}$ & $\begin{array}{l}\text { SL } \\
(\mathbf{m})\end{array}$ & $\mathbf{b}(\mathbf{m})$ & $\begin{array}{l}\text { HB } \\
(\mathbf{m})\end{array}$ \\
\hline 1 & $6^{\circ} 16^{\prime} 08^{\prime \prime}$ & $35^{\circ} 12^{\prime} 33^{\prime \prime}$ & 16 & 29.0 & 10.0 & 39.0 \\
\hline 2 & $6^{\circ} 20^{\prime} 48^{\prime \prime}$ & $35^{\circ} 05^{\prime} 40^{\prime \prime}$ & 23 & 1.8 & 38.2 & 40.0 \\
\hline 3 & $6^{\circ} 22^{\prime} 02^{\prime \prime}$ & $35^{\circ} 09^{\prime} 48^{\prime \prime}$ & 78 & 38.1 & 36.9 & 75.0 \\
\hline 4 & $6^{\circ} 20^{\prime} 16^{\prime \prime}$ & $35^{\circ} 05^{\prime} 01^{\prime \prime}$ & 34 & 6.4 & 41.6 & 48.0 \\
\hline 5 & $6^{\circ} 24^{\prime} 31^{\prime \prime}$ & $35^{\circ} 11^{\prime} 03^{\prime \prime}$ & 48 & 18.0 & 18.0 & 36.0 \\
\hline 6 & $6^{\circ} 17^{\prime} 54^{\prime \prime}$ & $35^{\circ} 13^{\prime} 18^{\prime \prime}$ & 67 & 27.4 & 17.6 & 45.0 \\
\hline 7 & $6^{\circ} 14^{\prime} 00^{\prime \prime}$ & $35^{\circ} 09^{\prime} 36^{\prime \prime}$ & 20 & 11.4 & 26.6 & 38.0 \\
\hline 8 & $6^{\circ} 16^{\prime} 49^{\prime \prime}$ & $35^{\circ} 12^{\prime} 10^{\prime \prime}$ & 62 & 21.3 & 23.7 & 45.0 \\
\hline 9 & $6^{\circ} 17^{\prime} 10^{\prime \prime}$ & $35^{\circ} 11^{\prime} 57^{\prime \prime}$ & 78 & 31.8 & 25.2 & 57.0 \\
\hline 10 & $6^{\circ} 16^{\prime} 00^{\prime \prime}$ & $35^{\circ} 12^{\prime} 35^{\prime \prime}$ & 18 & 5.0 & 18.0 & 23.0 \\
\hline 11 & $6^{\circ} 20^{\prime} 55^{\prime \prime}$ & $35^{\circ} 10^{\prime} 22^{\prime \prime}$ & 70 & 27.0 & 29.0 & 56.0 \\
\hline 12 & $6^{\circ} 13^{\prime} 15^{\prime \prime}$ & $35^{\circ} 07^{\prime} 26^{\prime \prime}$ & 17 & 5.7 & 30.3 & 36.0 \\
\hline 13 & $6^{\circ} 16^{\prime} 14^{\prime \prime}$ & $35^{\circ} 08^{\prime} 54^{\prime \prime}$ & 50 & 20.0 & 49.0 & 69.0 \\
\hline 14 & $6^{\circ} 22^{\prime} 01^{\prime \prime}$ & $35^{\circ} 08^{\prime} 58^{\prime \prime}$ & 73 & 31.1 & 44.9 & 76.0 \\
\hline 15 & $6^{\circ} 18^{\prime} 22^{\prime \prime}$ & $35^{\circ} 07^{\prime} 18^{\prime \prime}$ & 47 & 19.5 & 33.5 & 53.0 \\
\hline 16 & $6^{\circ} 22^{\prime} 39^{\prime \prime}$ & $35^{\circ} 07^{\prime} 44^{\prime \prime}$ & 4 & 2.9 & 24.1 & 27.0 \\
\hline 17 & $6^{\circ} 22^{\prime} 30^{\prime \prime}$ & $35^{\circ} 07^{\prime} 29^{\prime \prime}$ & 5 & 1.3 & 36.7 & 38.0 \\
\hline 18 & $6^{\circ} 22^{\prime} 36^{\prime \prime}$ & $35^{\circ} 07^{\prime} 42^{\prime \prime}$ & 6 & 2.7 & 20.3 & 23.0 \\
\hline 19 & $6^{\circ} 22^{\prime} 36^{\prime \prime}$ & $35^{\circ} 07^{\prime} 47^{\prime \prime}$ & 6 & 3.6 & 18.4 & 22.0 \\
\hline 20 & $6^{\circ} 233^{\prime} 36^{\prime \prime}$ & $35^{\circ} 07^{\prime} 54^{\prime \prime}$ & 6 & 3.7 & 17.3 & 21.0 \\
\hline 21 & $6^{\circ} 23^{\prime} 35^{\prime \prime}$ & $35^{\circ} 07^{\prime} 48^{\prime \prime}$ & 4 & 2.0 & 26.0 & 28.0 \\
\hline 22 & $6^{\circ} 22^{\prime} 11^{\prime \prime}$ & $35^{\circ} 09^{\prime} 12^{\prime \prime}$ & 74 & 39.5 & 30.5 & 70.0 \\
\hline 23 & $6^{\circ} 23^{\prime} 24^{\prime \prime}$ & $35^{\circ} 08^{\prime} 06^{\prime \prime}$ & 8 & 3.6 & 17.4 & 21.0 \\
\hline 24 & $6^{\circ} 23^{\prime} 39^{\prime \prime}$ & $35^{\circ} 08^{\prime} 18^{\prime \prime}$ & 7 & 5.0 & 29.0 & 34.0 \\
\hline 25 & $6^{\circ} 22^{\prime} 01^{\prime \prime}$ & $35^{\circ} 08^{\prime} 58^{\prime \prime}$ & 73 & 31.1 & 44.9 & 76.0 \\
\hline 26 & $6^{\circ} 18^{\prime} 43^{\prime \prime}$ & $35^{\circ} 02^{\prime} 38^{\prime \prime}$ & 45 & 41.4 & 51.6 & 93.0 \\
\hline 27 & $6^{\circ} 24^{\prime} 37^{\prime \prime}$ & $35^{\circ} 10^{\prime} 45^{\prime \prime}$ & 31 & 14.0 & 7.0 & 21.0 \\
\hline 28 & $6^{\circ} 15^{\prime} 58^{\prime \prime}$ & $35^{\circ} 11^{\prime} 42^{\prime \prime}$ & 21 & 3.6 & 29.4 & 33.0 \\
\hline 29 & $6^{\circ} 15^{\prime} 51^{\prime \prime}$ & $35^{\circ} 11^{\prime} 50^{\prime \prime}$ & 15 & 2.3 & 22.7 & 25.0 \\
\hline 30 & $6^{\circ} 17^{\prime} 04^{\prime \prime}$ & $35^{\circ} 12^{\prime} 19^{\prime \prime}$ & 70 & 28.2 & 34.8 & 63.0 \\
\hline 31 & $6^{\circ} 16 ’ 57 "$ & $35^{\circ} 12^{\prime} 13^{\prime \prime}$ & 69 & 20.9 & 31.1 & 52.0 \\
\hline 32 & $6^{\circ} 16^{\prime} 11^{\prime \prime}$ & $35^{\circ} 12^{\prime} 12^{\prime \prime}$ & 15 & 4.2 & 14.8 & 19.0 \\
\hline 33 & $6^{\circ} 16^{\prime} 32^{\prime \prime}$ & $35^{\circ} 12^{\prime} 19^{\prime \prime}$ & 35 & 11.4 & 19.6 & 31.0 \\
\hline 34 & $6^{\circ} 11^{\prime} 20^{\prime \prime}$ & $35^{\circ} 05^{\prime} 22^{\prime \prime}$ & 40 & 32.6 & 40.4 & 73.0 \\
\hline 35 & $6^{\circ} 11^{\prime} 30^{\prime \prime}$ & $35^{\circ} 05^{\prime} 20^{\prime \prime}$ & 34 & 31.6 & 23.4 & 55.0 \\
\hline 36 & $6^{\circ} 13^{\prime} 57^{\prime \prime}$ & $35^{\circ} 02^{\prime} 44^{\prime \prime}$ & 40 & 29.4 & 53.6 & 83.0 \\
\hline 37 & $6^{\circ} 22^{\prime} 44^{\prime \prime}$ & $35^{\circ} 08^{\prime} 19^{\prime \prime}$ & 38 & 18.3 & 29.7 & 48.0 \\
\hline 38 & $6^{\circ} 15^{\prime} 51^{\prime \prime}$ & $35^{\circ} 04^{\prime} 00^{\prime \prime}$ & 7 & 2.7 & 61.3 & 64.0 \\
\hline
\end{tabular}

The transverse resistance map presents areas with more prominent anomalies in its NE portion (values greater than $34,000 \mathrm{Ohm} \cdot \mathrm{m}^{2}$ ). It should be noted that, in this case, such high values are theoretically associated with high resistivity, i.e., associated with quartz-dominated sandstones and, therefore, with higher hydraulic conductivity and/or greater thickness. The highest hydraulic conductivities are theoretically related to well-sorted sandstones and high electrical resistivities in saturated zones.

In general, two main fault trends occur in the Catu River basin: NW-SE- and NE-SW-striking faults. These structures control the geometry of the Barreiras Aquifer in the study area. The hydrogeological basement map (Fig. 8) exhibits depth variations on the top of the calciferous sandstone or marl layer due to vertical throws. This behavior was also observed to the south and to the north of the study area (Lucena et al. 2013). These data also indicate that the Catu River basin exhibits structural characteristics of a horst. However, this horst presents a complex internal structure, which influences the local thickness of the Barreiras Aquifer. The hydrogeophysical cross-sections (Fig. 7) exhibit thickness variations within the Barreiras Aquifer. The A-A' and B-B' cross-sections indicate the existence of depressions that are associated with the valleys of the Jacu (north) and Curimataú (south) rivers, which both correspond to the grabens identified in previous studies (Bezerra et al. 2001). Important throws were identified in the C-C ' and D-D' cross-sections, which were also associated with variations in the saturated thickness.

The saturated thickness map (Fig. 9) exhibits a direct correlation with the hydrogeological basement map (Fig. 6) and the structural features (Fig. 8). In this context, we emphasize a saturated thickness anomaly in the northeastern portion of the Catu River basin, which is associated with the downfaulting of the hydrogeological basement. The same anomalous feature is observed in the transverse resistance map (Fig. 10), which shows a direct relationship between the thickness of the aquifer and its hydrogeological basement. This association indicates the predominance of the saturated thickness parameter over their respective resistivities. In addition, considering the largest values of transverse resistance, along with

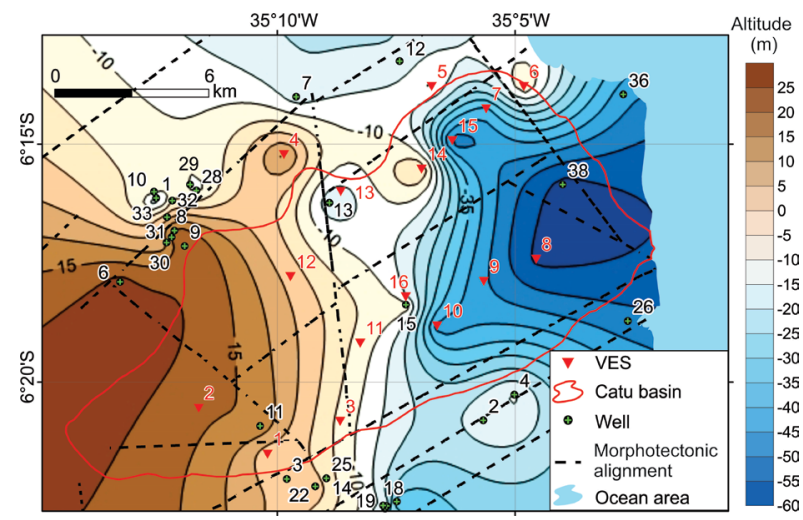

Figure 6. Hydrogeological basement map of the Barreiras Aquifer and morphotectonic alignments (black lines). The map shows the $\mathrm{W}$-E-oriented regional gradient and specific punctual anomalies associated with the downfaulting of calciferous sandstone or marl. 
the equipotential arrangement in the potentiometric map (Fig. 2), one of the most promising hydrogeological potential areas occurs in the northeast sector of the basin. There, the largest spacing between the equipotential lines are arranged in places of larger transverse resistance, the latter being primarily associated with faults.
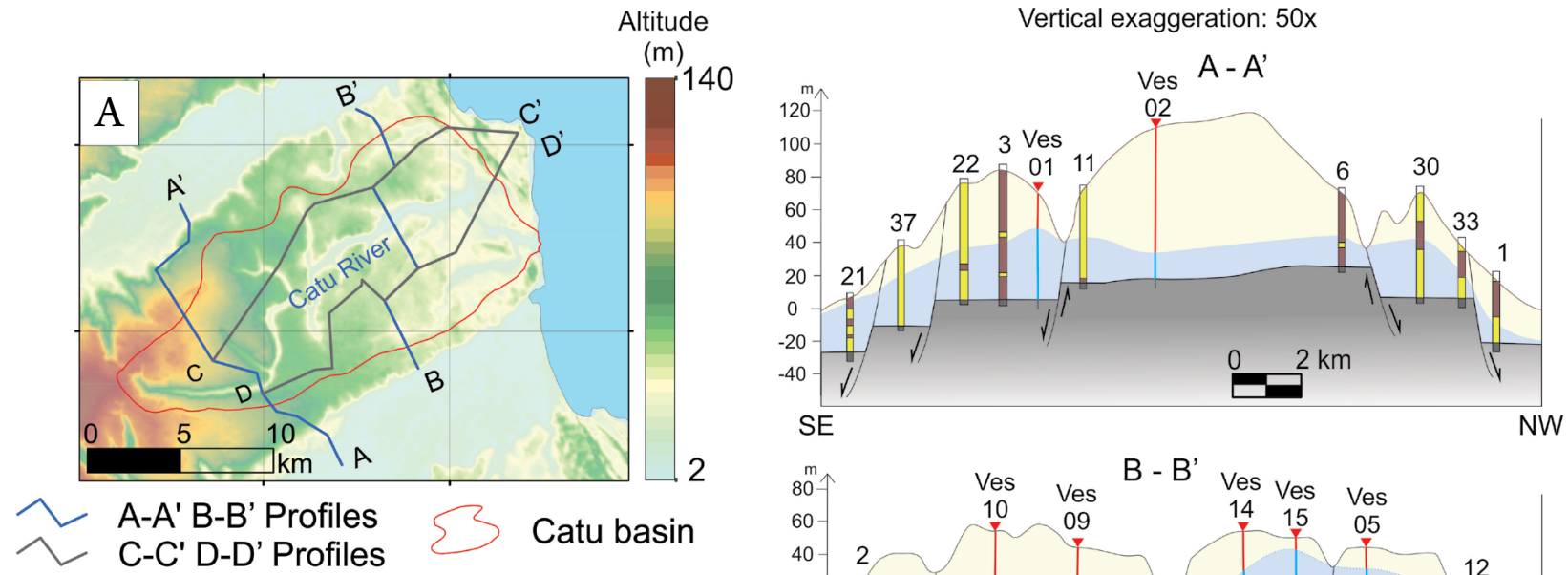

Lithology in well profile

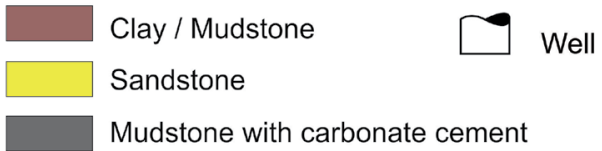

Structural geology

- Geology contact

_ - Inferred fault

ل/I Normal fault

\section{Hydrogeophysics}

$\nabla$ VES

Inferred potentiometric surface (SL)

$\rho>1000 \Omega m$

$350<\rho>950 \Omega m$

$\rho<100 \Omega m$

\section{Unsaturaded zone}

Saturaded zone (Barreiras aquifer) Hydrogeological basement
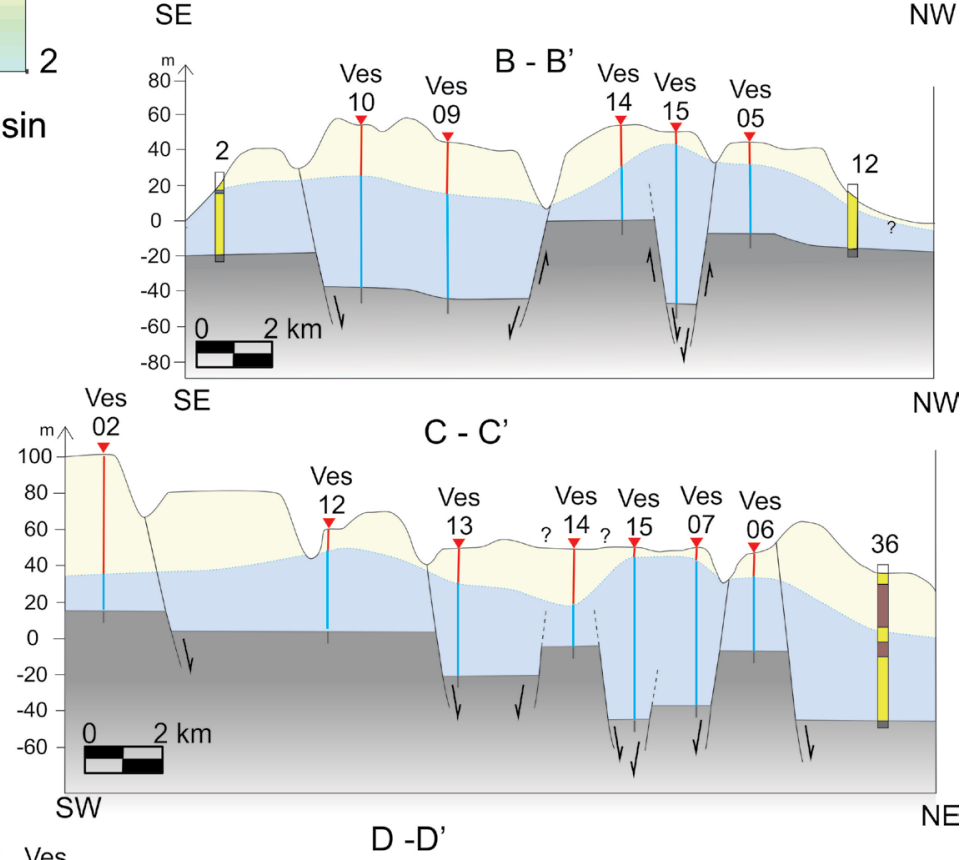

Figure 7. Hydrogeophysics cross sections based on the geomorphological and hydrogeophysical data analyses.

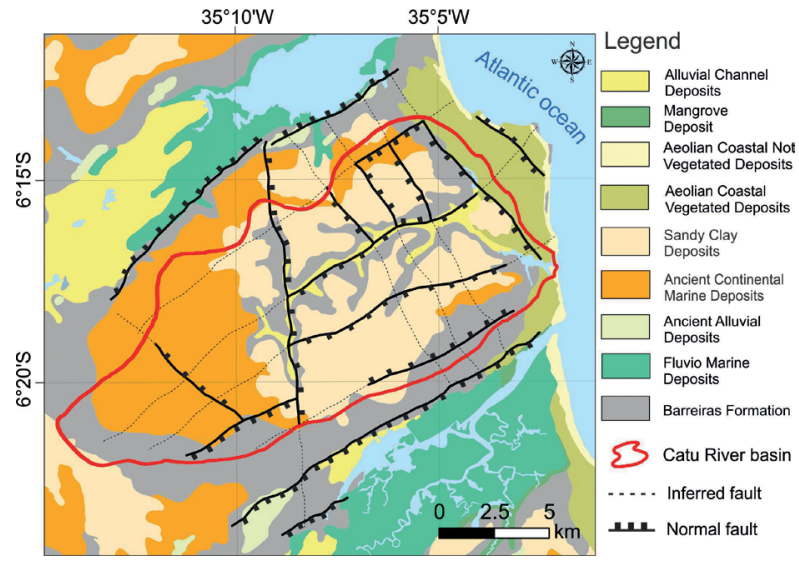

Figure 8. Structural-geologic map of the Catu River basin, showing the Neogene structural subdivision of the Barreiras Formation, related aquifer, and the Quaternary sedimentary units.

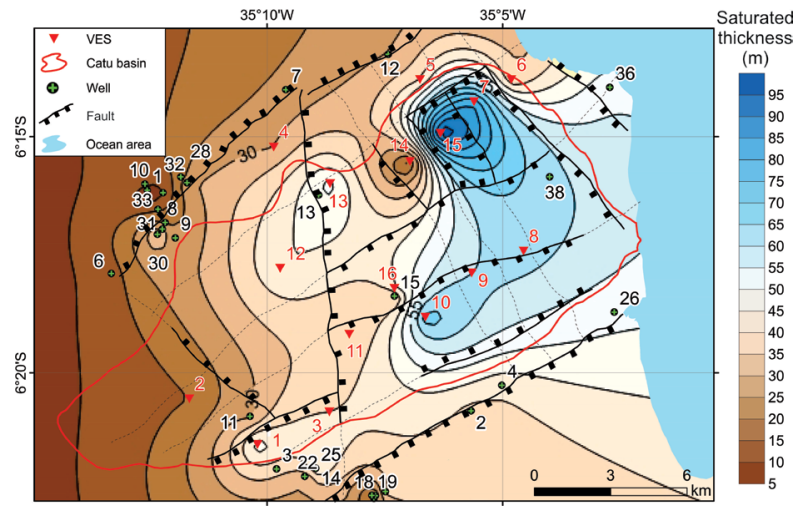

Figure 9. Saturated thickness map, with the highest values in the northeastern portion of the area (thicknesses greater than $60 \mathrm{~m}$ ). 


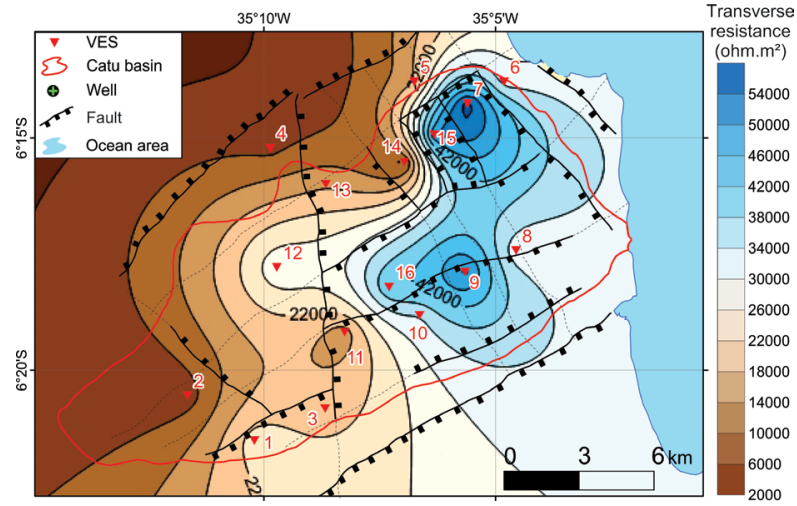

Figure 10. Transverse resistance map of the Barreiras Aquifer in the study area. The black lines represent faults.
Fig. 11 shows a schematic integration of the relationship among geomorphological features, hydrogeological features (thickness of Barreiras Aquifer), and the structural framework. This structural compartmentalization defined in the hydrogeophysical cross-sections, is controlled by normal faults. However, we do not rule out the possibility of strike-slip components in these structures.

\section{CONCLUSIONS}

This study presents a multidisciplinary approach based on the geomorphological, geological, hydrogeological and geoelectric analysis in a sedimentary aquifer. The geomorphological
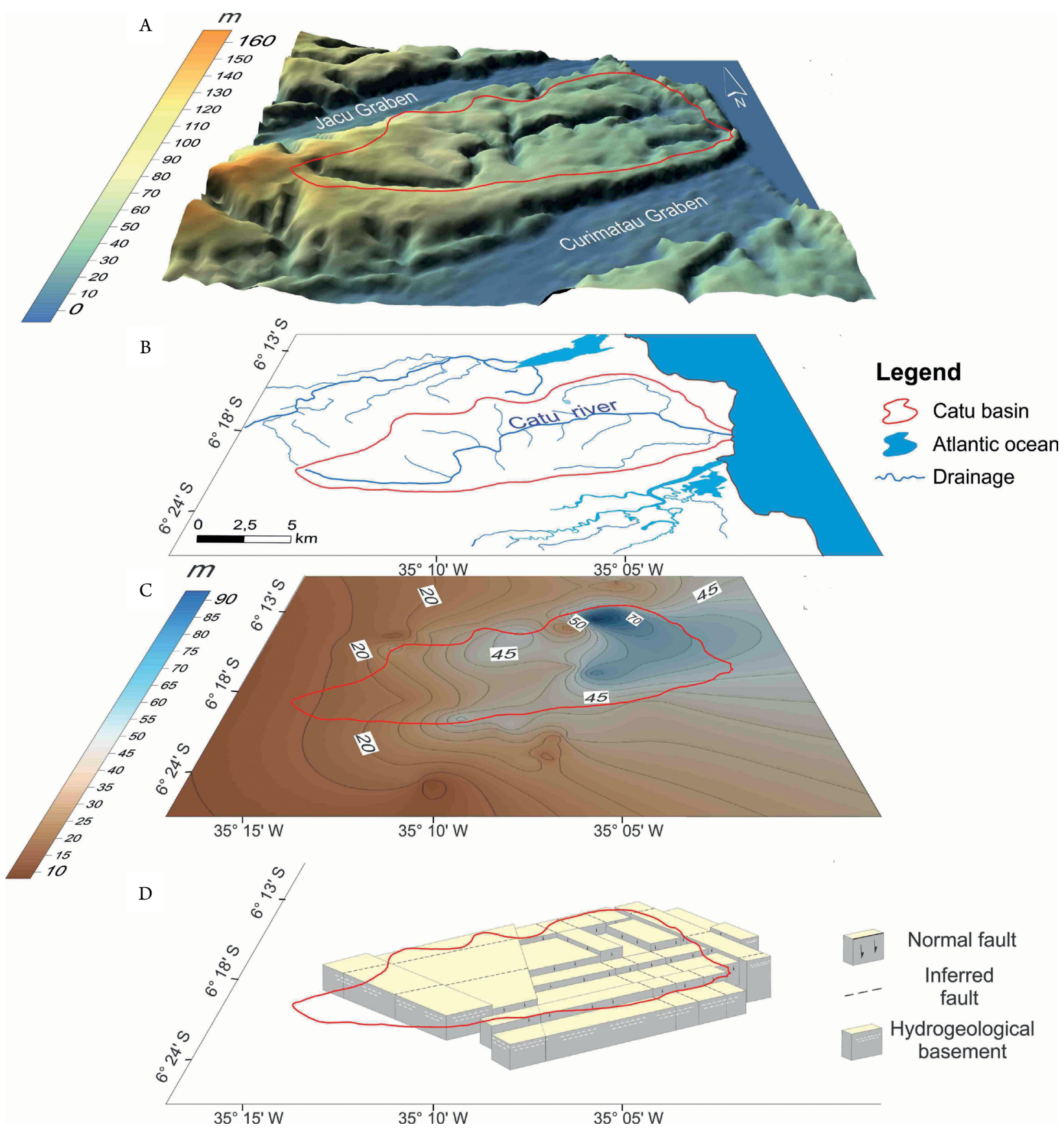

Figure 11. Integration of geomorphological, hydrogeological and geophysical data: (A) digital terrain model (SRTM) and morphological features; (B) drainage network; (C) thickness of the Barreiras Aquifer, emphasizing the highest values in the northeast portion of the basin; (D) schematic structural compartmentalization of the area, underlining the main aquifer thicknesses associated with downfaulting of the hydrogeological basement, represented by the calciferous sandstone or marl. 
analysis contributed to the understanding of the regional structure, which enabled the identification of the main regional NW-SE and NE-SW-striking fault. Topographic and drainage lineaments supported the identification of faults observed in the geophysical results.

The results obtained in the Barreiras Aquifer in the Catu River basin (Brazil) indicated a structural control of the aquifer thickness. The fault-controlled geometry of this reservoir was highlighted by variations on the top of the Mesozoic sedimentary units (calciferous sandstone or marl). This information was obtained from lithological profiles of wells and geoelectric surveys. The throws observed in hydrogeophysical cross-sections range from 10 to $44 \mathrm{~m}$. These cross-sections displayed faults affecting all Neogene sedimentary units and possible overlying Quaternary sedimentary units.

The transverse resistance and aquifer thickness indicate more prominent positive anomalies in the northeast sector of the study area, with values of $70 \mathrm{~m}$ and $50,000 \mathrm{Ohm} . \mathrm{m}^{2}$, respectively. These anomalies are directly associated with the hydrogeological basement of the Barreiras Aquifer and their respective thickness variations were induced by faults.
The hydrogeological basement map and the saturated thickness map showed a direct relationship with the aquifer thickness variations and the depth to the hydrogeophysical basement. These correlations were observed through the isoline behavior and faults. The transverse resistance map also reveals a direct relationship with thickness variations of the aquifer, which was used to suggest targets for future well drillings, particularly in the northeastern sector of the study area. The Barreiras Aquifer of the Catu River basin is a case study that indicates that porous aquifers in structural highs are also influenced by faults, which mainly control their geometry and transmissivity.

\section{ACKNOWLEDGEMENTS}

The authors thank the support of the National Council for Scientific and Technological Development (CNPq), grant 573462/2008-9. We also thank the corrections and comments from anonymous reviewers, the Associate Editor and the Brazilian Journal of Geology's Editor-in-Chief, Claudio Riccomini, who greatly improved the original work.

\section{ARTICLE INFORMATION}

Manuscript ID: 20170141. Received on: 11/29/2017. Approved on: 04/16/2019.

IS wrote the first draft of the manuscript and prepared all figures; LL provided advisorship regarding the methodology and its applications, as well as improved the manuscript through corrections and suggestions. FB provided advisorship regarding regional geology and the morphotectonic analysis; JF provided data on the potentiometric map and hydraulic parameters of Barreiras Aquifer.

Competing interests: The authors declare no competing interests.

\section{REFERENCES}

Balsamo F., Bezerra F.H.R., Vieira M.M., Storti F. 2013. Structural control on the formation of iron-oxide concretions and Liesegang bands in faulted, poorly lithified Cenozoic sandstones of the Paraíba Basin, Brazil. GSA Bulletin, 125(5-6):913-931. https://doi.org/10.1130/B30686.1

Bezerra F.H.R., Amaro V.E., Vita-Finzi C., Saadi A. 2001. PlioceneQuaternary fault control of sedimentation and coastal plain morphology in NE Brazil. Journal of South American Earth Sciences, 14(1):61-75. https:// doi.org/10.1016/S0895-9811(01)00009-8

Bezerra F.H.R., Brito Neves B.B., Corrêa A.C.B., Barreto A.M.F., Suguio K. 2008. Late Pleistocene tectonic-geomorphological development within a passive margin - the Cariatá trough, northeastern Brazil. Geomorphology, 97(3-4):555-582. https://doi.org/10.1016/j.geomorph.2007.09.008

Bezerra F.H.R., Rossetti D.F., Oliveira R.G., Medeiros W.E., Brito Neves B.B., Balsamo F., Nogueira F.C.C., Dantas E.L., Andrades Filho C., Goes A.M. 2014. Neotectonic reactivation of shear zones and implications for faulting style and geometry in the continental margin of NE Brazil. Tectonophysics, 614:78-90. https://doi.org/10.1016/j.tecto.2013.12.021

Bobachev A.A., Modin I.N., Shevnin V.A., 2000. IPI2Win v. 2.1, IPI_RES2, IPI_RES3, User's Guide. Geoscan-M Ltd, Moscou, 25 p.

Burazer M., Žitko V., Radaković D., Parezanović M. 2010. Using geophysical methods to define the attitude and extension of water-bearing strata in the Miocene sediments of the Pannonian Basin. Journal of Applied Geophysics, 72(4):242-253. https://doi.org/10.1016/j.jappgeo.2010.10.002

Chihi H., de Marsily G., Belayouni H., Yahyaoui H. 2015. Relationship between tectonic structures and hydrogeochemical compartmentalization in aquifers: example of the "Jeffara de Medenine" system, south-east Tunisia. Journal of Hydrology: Regional Studies, 4(Part B):410-430. https:// doi.org/10.1016/j.ejrh.2015.07.004

Christakos G. 2000. Modern Spatiotemporal Geostatistics. New York: Oxford University Press. $288 \mathrm{p}$
De Castro D.L., Bezerra F.H.R., Souza M.O.L., Fuck R.A. 2012. Influence of Neoproterozoic tectonic fabric on the origin of the Potiguar Basin, northeastern Brazil and its links with West Africa based on gravity and magnetic data. Journal of Geodynamics, 54:29-42. https://doi.org/10.1016/j. jog.2011.09.002

Díaz D., Maksymowicz A., Vargas G., Vera E., Contreras-Reyes E., Rebolledo S. 2014. Exploring the shallow structure of the San Ramón thrust fault in Santiago, Chile $\left(\sim 33.5^{\circ} \mathrm{S}\right)$, using active seismic and electric methods. Solid Earth, 5:837-849. https://doi.org/10.5194/se-5-837-2014

Esri ArcGIS for Windows. 2014. ArcGIS Desktop: ArcMap. Versão 10.2. [S.I.]: ESRI - Enviromental Systems Research Institute. 1CD-ROM.

Font-Capo J., Pujades E., Vázquez-Suñé E., Carrera J., Velasco V., Monfort D. 2015. Assessment of the barrier effect caused by underground constructions on porous aquifer with low hydraulic gradient: A case study of the metro construction in Barcelona, Spain. Engineering Geology, 196:238-250. https://doi.org/10.1016/j.enggeo.2015.07.006

Da Guia Lima M., Dantas E.P., Medeiros V.C. 2014. Programa Geologia do Brasil-PGB. São José do Mipibu. Folhas SB. 25-Y-A-II e SB.25-Y-AIII. Estados do Rio Grande do Norte e Paraíba. Carta Geológica. Recife: CPRM, mapa colorido, 100,0 x 71,0 cm. Escala 1:100.000. Available from: <http://rigeo.cprm.gov.br/jspui/bitstream/doc/17627/3/mapa_sjose_ mipibu.pdf $>$ Accessed on: April 02, 2016.

Landon M.K., Morita A.Y., Nawikas J.M., Christensen A.H., Faunt C.C., Langenheim V.E. 2015. Aquifer geometry, lithology, and water levels in the Anza-Terwilliger Area - 2013, Riverside and San Diego Counties, California. U.S. Geological Survey Scientific Investigations, Report 20155131, 30 p. https://doi.org/10.3133/sir20155131

Lima C.C.U., Bezerra F.H.R., Nogueira F.C.C., Maia R.P., Sousa M.O.L. 2014. Quaternary fault control on the coastal sedimentation and morphology of the São Francisco coastal plain, Brazil. Tectonophysics, 633: 98-114. https:// doi.org/10.1016/j.tecto.2014.06.026 
Braz. J. Geol. (2019), 49(2): e20170141

Lucena L.R.F. 2005. Implicação da compartimentação estrutural no Aqüifero Barreiras na área da bacia do Rio Pirangi-RN. Tese de Doutorado, Universidade Federal do Paraná, Curitiba. 151 p.

Lucena L.R.F., Oliveira J.J.G., Medeiros W.E., Queiroz M.A. 2013. The potential of the Barreiras Aquifer in the lower course of the Doce River, Rio Grande do Norte, northeast Brazil - Integration of hydrogeological and geophysical data. Brazilian Journal Geophysics, 31(1):43-57. https://doi. org/10.22564/rbgf.v31i1.245

Lucena L.R.F., Da Silva, L.R.D., Vieira M.M., Carvalho B.M., Xavier Júnior M.M. 2016. Estimating hydraulic parameters of Açu-Brazil aquifer using the computer analysis of micrographs. Journal of Hydrology, 535:61-70. https:// doi.org/10.1016/j.jhydrol.2016.01.025

Monteiro A.R.O. 2015. Análise do grau de proteção do Aquífero Barreiras em perímetros sob fertilização química a partir de dados hidrogeofísicos - Área da Bacia do Rio Catu-RN. Dissertação de Mestrado, Universidade Federal do Rio Grande do Norte, Natal. 108 p.

Moulin M., Fluteau F., Courtillot V., Marsh J., Delpech G., Quidelleur X., Gérard M., Jay A.E. 2011. An attempt to constrain the age, duration, and eruptive history of the Karoo flood basalt: Naude's Nek section (South Africa). Journal of Geophysical Research, 116(B7):1-27. https://doi.org/10.1029/2011JB008210
Orellana E. 1972. Prospección geoeléctrica en corriente continua. Ed. Paraninfo, Madrid. 523 p.

Pujades E, López A, Carrera J, Vázquez-Suñé E, Jurado A. 2012. Barrier effect of underground structures on aquifers. Engineering Geology. 145146:41-49. https://doi.org/10.1016/j.enggeo.2012.07.004

Rossetti D.F., Bezerra F.H.R., Góes A.M., Neves B.B.B. 2011. Sediment deformation in Miocene and post-Miocene strata, Northeastern Brazil: Evidence for paleoseismicity in a passive margin. Sedimentary Geology, 235(3-4):172-187. https://doi.org/10.1016/j.sedgeo.2010.02.005

Rossetti D.F., Bezerra F.H.R., Dominguez J.M.L. 2013. Late OligoceneMiocene transgressions along the equatorial and eastern margins of Brazil. EarthScience Reviews, 123:87-112. https://doi.org/10.1016/j.earscirev.2013.04.005

Utom A.U., Odoh B.I., Okoro A.U. 2012. Estimation of aquifer transmissivity using dar zarrouk parameters derived from surface resistivity measurements: A case history from parts of Enugu Town (Nigeria). Journal of Water Resource and Protection, 4(12):993-1000. https://doi.org/10.4236/ jwarp.2012.412115

Valeriano M.M., Albuquerque C.G. 2010. TOPODATA: Processamento dos dados SRTM. São José dos Campos, Instituto Nacional do Pesquisas Espaciais - INPE, 79 pp. (INPE-16702-RPQ/854). Available from: <http://www.dsr.inpe.br/topodata>. Accessed on: June 11, 2015. 